SHORT COMMUNICATION

\title{
Description of the female and larval stage of Denopelopia amicitia Dantas, Hamada \& Mendes (Diptera: Chironomidae)
}

\author{
Galileu P.S. DANTAS ${ }^{1 *}$, , Neusa HAMADA² \\ Instituto Nacional de Pesquisas da Amazônia, Programa de Pós-Graduação em Entomologia, CP 478, 69067-375, Manaus, AM, Brazil \\ 2 Instituto Nacional de Pesquisas da Amazônia, Coordenação de Biodiversidade (CoBio), CP 478, 69067-375, Manaus, AM, Brazil \\ * Corresponding author: galileu.psd@gmail.com; (iD https://orcid.org/0000-0002-9155-533X
}

\begin{abstract}
Denopelopia amicitia Dantas, Hamada \& Mendes was described based on the male and pupae collected in the Brazilian Amazon. Here we describe and illustrate the female and larva of this species. At both stages, D. amicitia is similar to Denopelopia atria Roback \& Rutter, which is the only species in the genus with all life stages known until now.

KEYWORDS: aquatic insects, Tanypodinae, Pentaneurini, Amazonia, Brazil

\section{Descrição da fêmea e do estágio larval de Denopelopia amicitia Dantas, Hamada \& Mendes (Diptera: Chironomidae)}

\section{RESUMO}

Denopelopia amicitia Dantas, Hamada \& Mendes foi descrita com base no macho e na pupa coletados na Amazônia brasileira. Aqui descrevemos e ilustramos a fêmea e a larva desta espécie. Em ambos os estágios, D. amicitia é similar à Denopelopia atria Roback \& Rutter, que é a única espécie do gênero com todos os estágios de vida conhecidos até agora.

Palavras-CHaVE: insetos aquáticos, Tanypodinae, Pentaneurini, Amazônia, Brasil

Denopelopia Roback \& Rutter is a small chironomid genus with six valid species, of which only $D$. atria Roback $\&$ Rutter, 1988 has all life stages known. D. amicitia Dantas, Hamada \& Mendes, 2016 is known as male and pupa, and all other species are known as adult male only. Based on adult morphology, Denopelopia seems to be most related to Telmatopelopia and Zavrelimyia (Roback and Rutter 1988). However, the wing C of Telmatopelopia and Zavrelimyia is slightly produced beyond $\mathrm{R}_{4+5}$ and ends above or slightly beyond $\mathrm{M}_{1+2}$, contrasting with Denopelopia, in which $\mathrm{C}$ is not produced and ends clearly before $\mathrm{M}_{1+2}$ (Murray and Fittkau 1989). According to Roback and Rutter (1988), the female of Denopelopia differs from that of Zavrelimyia in having the anterior end of notum slightly expanded and the ramus broader. Furthermore, the female of Denopelopia has three seminal capsules, differing from that of Telmatopelopia, which possess only two (Rodova 1971; Saether 1977). The genus has a discontinuous distribution around the world, with one Nearctic, two Neotropical, two Oriental and one Palearctic/Oriental species (Cheng and Wang 2005; Ashe and O'Connor 2009; Dantas et al. 2016).
Recently, a Pentaneurini larva collected near the type locality of $D$. amicitia was reared and associated with the pupa and female, which was subsequently identified as $D$. amicitia. In the present study, female and larva of $D$. amicitia are described and illustrated.

Larvae were collected associated with aquatic vegetation using an aquatic hand net. In the laboratory, they were individually reared in a $20-\mathrm{mL}$ plastic vial. Chironominae larvae were provided as food every two days. For further details on rearing techniques, see Mendes (2002). Emerged adults were kept alive for at least 24 hours before being fixed in $80 \%$ ethanol to adequately preserve the coloration. The material examined was slide-mounted in Euparal', following the procedures outlined by Pinder (1983, 1986, 1989). The general terminology follows Sxther (1980). The holotype of $D$. amicitia was examined to certify the identification of the reared specimen. The material is housed in the Invertebrate Collection of the Instituto Nacional de Pesquisas da Amazônia (INPA), Manaus, Amazonas, Brazil. 


\section{Taxonomic treatment}

Family: Chironomidae Newman, 1834

Subfamily: Tanypodinae Kieffer, 1906

Tribe: Pentaneurini Fittkau, 1962

Genus: Denopelopia Roback \& Rutter, 1988

\section{Denopelopia amicitia Dantas, Hamada \& Mendes, 2016}

urn:lsid:zoobank.org:act:09A94352-BDD3-423A-A61B1740C1452F0C

http://zoobank.org/References/47E3D9BC-9227-4003B3E8-D9081D4DFA7D

Material examined. Holotype male with pupal exuvia, Brazil, Amazonas State, Presidente Figueiredo, pisciculture pond, BR 174-Km 121, $01^{\circ} 55^{\prime} 50.2^{\prime \prime} \mathrm{S}, 60^{\circ} 03^{\prime} 02.0^{\prime \prime} \mathrm{W}, 10 /$ xii/2012, G.P.S. Dantas, (INPA); 1 female with pupal and larval exuviae, Presidente Figueiredo, tributary of the igarapé da Onça, $02^{\circ} 02^{\prime 2} 22^{\prime \prime S}, 59^{\circ} 51^{\prime} 03^{\prime \prime W}$, 11.iii.2019, G.P.S. Dantas (INPA).

Diagnostic characters. Female: tibial spurs with three teeth, tibial comb on hind leg with six bristles. Larva: VP antero-lateral to SSm; tips of the internal teeth of the ligula directed outwards.

Female $(\mathrm{n}=1)$. Total length $1.46 \mathrm{~mm}$; wing length 1.09 $\mathrm{mm}$; total length/wing length 1.33 ; wing length/length of profemur 1.89 .

Coloration. Head brown. Thorax almost completely brown, as in Figure 1b. Wing darker at the basal 1/3, membrane covered with macrotrichia, as in Figure 1c. Legs: femurs and tibiae light-brown, $\mathrm{ta}_{1}-{ }_{5}$ pale. Abdomen brown.

Head (Figure 1a). AR 0.24. Antenna with 11 flagellomeres; apical flagellomere $124 \mu \mathrm{m}$ long; $25 \mu \mathrm{m}$ wide, with one apical seta $92 \mu \mathrm{m}$ long; pedicel with seven setae; scape with five setae. Eyes bare; dorsomedial extension well developed, $78 \mu \mathrm{m}$ long, $72 \mu \mathrm{m}$ wide, medially separated by $77 \mu \mathrm{m}$. Temporal setae 11, uniserial. Clypeus $110 \mu \mathrm{m}$ long, $80 \mu \mathrm{m}$ wide, with 21 setae. Cibarial pump with anterior margin concave, 217 $\mu \mathrm{m}$ long and with orifice 87 from apex. Tentorium $132 \mu \mathrm{m}$ long. Palpomere lengths (1-5): 34, 64, 126, 147 and $265 \mu \mathrm{m}$.

Thorax (Figure 1b). Scutal tubercle absent. Acrosthicals 30 ; dorsocentrals 17, biserial anteriorly, uniserial posteriorly; prealars 7-8; one supraalar. Antepronotum with one lateral seta, small tubercle present. Scutellum with 15 setae, biserial. Posnotum without setae.

Wing (Figure 1c). Width $0.49 \mathrm{~mm}$. Membrane covered with macrotrichia. Costa not produced beyond apex of $\mathrm{R}_{4+5}$. $\mathrm{MCu}$ proximal to the RM. Brachiolum with three setae. Squama with 10 setae. Anal lobe moderately developed. VR 0.92; WW 0.45 .

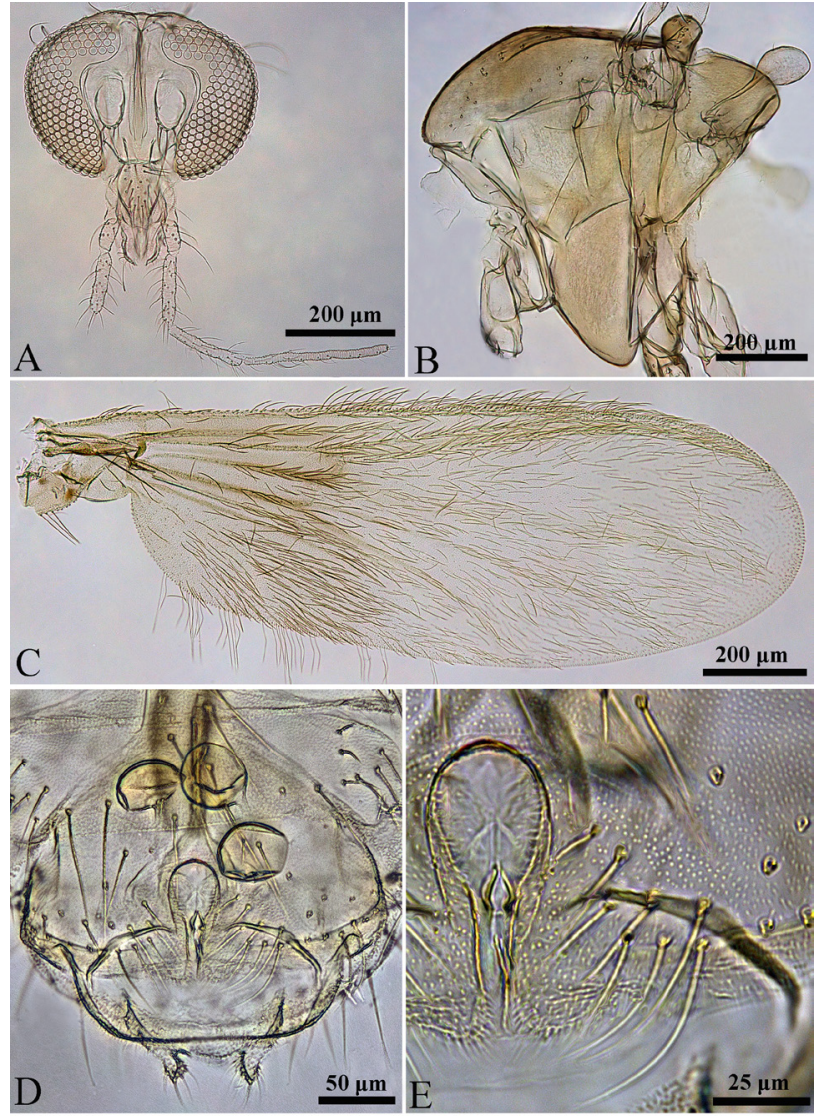

Figure 1. Denopelopia amicitia, female. A - Head, dorsal view; B - Thorax, lateral view; C - Wing; D - Genitalia, ventral view; E - Gonapophysis VIII and coxosternapodeme, ventral view. This figure is in color in the electronic version.

Legs. Foretibia $38 \mu \mathrm{m}$ wide at apex, with one apical spur, 61 $\mu \mathrm{m}$ long, bearing three teeth. Mid tibia $38 \mu \mathrm{m}$ wide at apex, with two apical spurs, 25 and $50 \mu \mathrm{m}$ long, each bearing three teeth. Hind tibia $40 \mu \mathrm{m}$ wide at apex, with two apical spurs, 30 and $65 \mu \mathrm{m}$ long, each bearing three teeth; tibial comb with six bristles. Claws slender and distally pointed. Lengths (in $\mu \mathrm{m})$ and proportions of leg segments as in Table 1.

Genitalia (Figure 1d-e). Tergite IX without setae. Three spherical seminal capsules, with $48 \mu \mathrm{m}$ in diameter; spermathecal ducts separate for all their length, special secretory cells present. Gonapophysis VIII rounded at apex. Coxosternapodeme curved at the ends, slightly swollen at the mid-length, $96 \mu \mathrm{m}$ long. Tergite $\mathrm{X}$ with about 14 setae on each side. Notum $102 \mu \mathrm{m}$ long; ramus $65 \mu \mathrm{m}$ long. Cercus $21 \mu \mathrm{m}$ long.

Table 1. Lengths (in $\mu \mathrm{m}$ ) and proportions of the female legs of Denopelopia $\operatorname{amicitia}(\mathrm{n}=1)$

\begin{tabular}{lcccccccccc}
\hline & $\mathrm{Fe}$ & $\mathrm{ti}$ & $\mathrm{ta}_{1}$ & $\mathrm{ta}_{2}$ & $\mathrm{ta}_{3}$ & $\mathrm{ta}_{4}$ & $\mathrm{ta}_{5}$ & $\mathrm{LR}$ & $\mathrm{BV}$ & $\mathrm{SV}$ \\
\hline $\mathrm{P}_{1}$ & 572 & 702 & 506 & 258 & 210 & 137 & 82 & 0.72 & 2.59 & 2.52 \\
$\mathrm{P}_{2}$ & 650 & 720 & 435 & 225 & 155 & 100 & 76 & 0.60 & 3.25 & 3.15 \\
$\mathrm{P}_{3}$ & 611 & 827 & 557 & 290 & 226 & 137 & 87 & 0.67 & 2.70 & 2.58 \\
\hline
\end{tabular}




\section{Larva $(\mathrm{n}=1)$.}

Coloration. Head brownish yellow; postoccipital margin brown; apex of mandible dark-brown; ligula brown, darker at apex. Procercus pale brown, anal setae brown. All posterior parapod claws pale yellow.

Head (Figure 2a). Head capsule elongated; cephalic index 0.59. Chaetotaxy as in Figure 2b-c. Dorsally S5, S8 and S7 in a triangular arrangement, DP absent. Ventrally SSm, S9 and S10 nearly aligned diagonally, VP larger than the setal pits, posterior to S10, slightly antero-lateral to SSm. SSm bifid, S9 simple, S10 simple.

Antenna. Length $397 \mu \mathrm{m}, \mathrm{A}_{1} 290 \mu \mathrm{m}$ long, $22 \mu \mathrm{m}$ wide, with ring organ placed $174 \mu \mathrm{m}$ from base, $\mathrm{A}_{2} 99 \mu \mathrm{m}$ long, $\mathrm{A}_{3} 5 \mu \mathrm{m}$ long, $\mathrm{A}_{4} 4 \mu \mathrm{m}$ long, blade $104 \mu \mathrm{m}$ long, accessory blade $95 \mu \mathrm{m}$ long. AR 2.71 .

Maxilla. Basal palp segment $45 \mu \mathrm{m}$ long and $11 \mu \mathrm{m}$ wide, arising from a prominent tubercle, with ring organ placed 27 $\mu \mathrm{m}$ from the base. A1/P1 6.44, A2/P1 2.20.

Mandible. Gradually curved, $115 \mu \mathrm{m}$ long, with three lateral setae and one sensilla. Mola distally expanded to a protruding tooth apically directed and conical; inner tooth easily visible, immediately distal to mola. A1/MD 2.52.

Mentum and $M$ appendage. Dorsomental teeth reduced, labial vesicles well-developed, egg-shaped. $\mathrm{M}$ appendage bluntly rounded apically; pseudoradula $76 \mu \mathrm{m}$ long, $33 \mu \mathrm{m}$ wide at base, uniformly granulated.

Hypopharyngeal complex (Figure 2d). Ligula with five teeth, anterior row of teeth straight; $73 \mu \mathrm{m}$ long, 47, 27 and $43 \mu \mathrm{m}$ wide at apex, middle and base respectively; tips of inner teeth strongly directed outwards. Paraligula trifid, two inner teeth shorter than apical tooth; $40 \mu \mathrm{m}$ long, $7 \mu \mathrm{m}$ wide. Pecten hypopharyngis with about 12 teeth.

Body. Without swim hairs. Anterior parapods with simple claws. Posterior parapod (Figure 2e) apex with hooklets, numerous simple claws and two smaller forked claws, with a small spine on the outer margin (Figure 2f); the claws can be completely retracted into the parapods. Subasal seta of posterior parapod simple, $210 \mu \mathrm{m}$ long. Procercus $164 \mu \mathrm{m}$ long, $35 \mu \mathrm{m}$ wide at base, with eight anal setae each, about $620 \mu \mathrm{m}$ long. L/W 4.68. Supraanal seta $275 \mu \mathrm{m}$ long. Anal tubules $207 \mu \mathrm{m}$ long.

\section{Taxonomic comments}

A better knowledge on immature stages and the female, and a higher taxonomic resolution can support the use of non-biting midges in a wider range of fields such as ecology, biogeography and phylogenetic (Ekrem et al. 2010). However, in many Chironomidae groups, females and larvae of different species of the same genus, and even of closely related genera, are difficult to be characterized and distinguished due to their morphological homogeneity. Indeed, in many cases

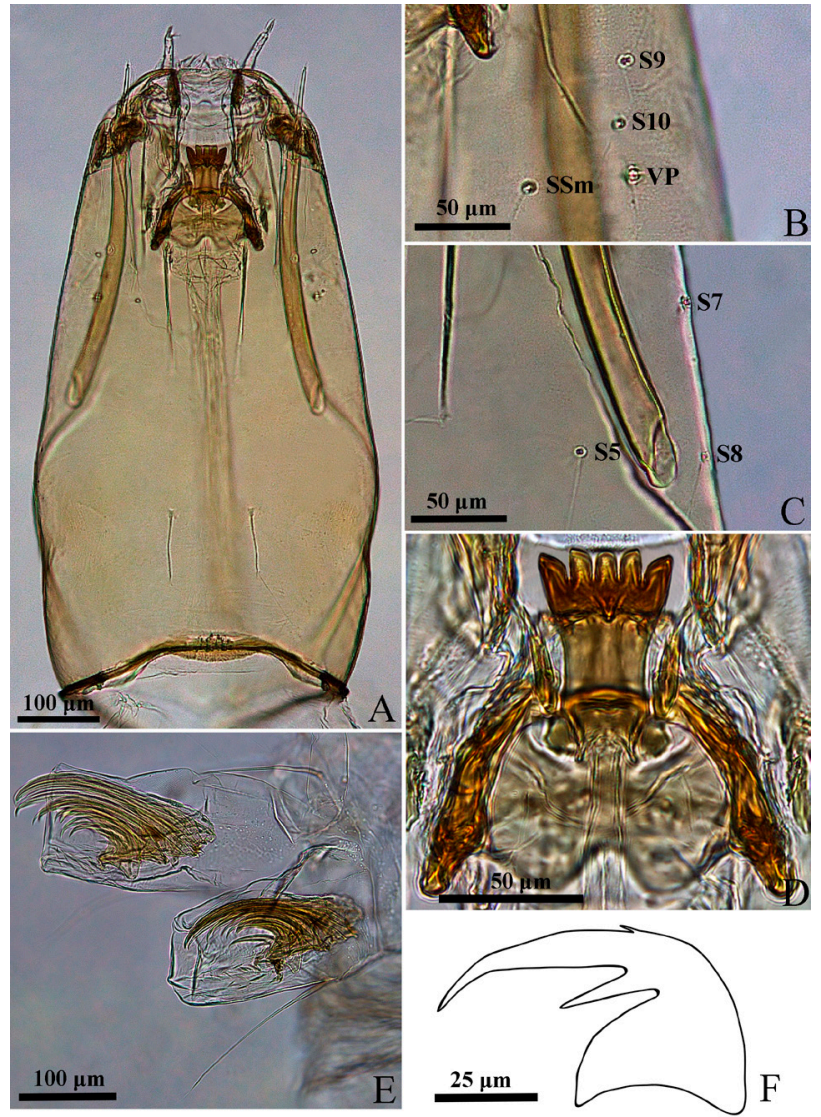

Figure 2. Denopelopia amicitia, larva. A - Head capsule, ventral view; B Chaetotaxy of the head, ventrally; C-Chaetotaxy of the head, dorsally; D - Ligula and paraligula, ventral view; E - Posterior parapods, lateral view; F - Bifid claw of posterior parapod, lateral view. This figure is in color in the electronic version.

species-level identification of larvae and females is only possible in association with the male adult. Of the six known species in Denopelopia, D. atria was the only one with female and larva described so far, which limits the understanding of interspecific morphological differences. Females of $D$. amicitia and $D$. atria are quite similar, therefore it is difficult to distinguish them. The only observed differences were the number of teeth in tibial spurs (four teeth in D. atria and three in $D$. amicitia) and the number of bristles of the tibial comb (six in D. amicitia and seven in D. atria). The larva of $D$. amicitia is also very similar to that of $D$. atria, but it can be distinguished by having VP antero-lateral to SSm and the tips of internal teeth of the ligula directed outwards, contrasting with the larva of $D$. atria, with VP lateral or postero-lateral to $\mathrm{SSm}$, and the tips of the internal teeth of the ligula anteriorly directed. It is worth mentioning, however, that the two larval features of $D$. atria referred above, were determined with base on illustrations and description provided by Roback and Rutter (1988) and on photos available in Cranston (2010). 


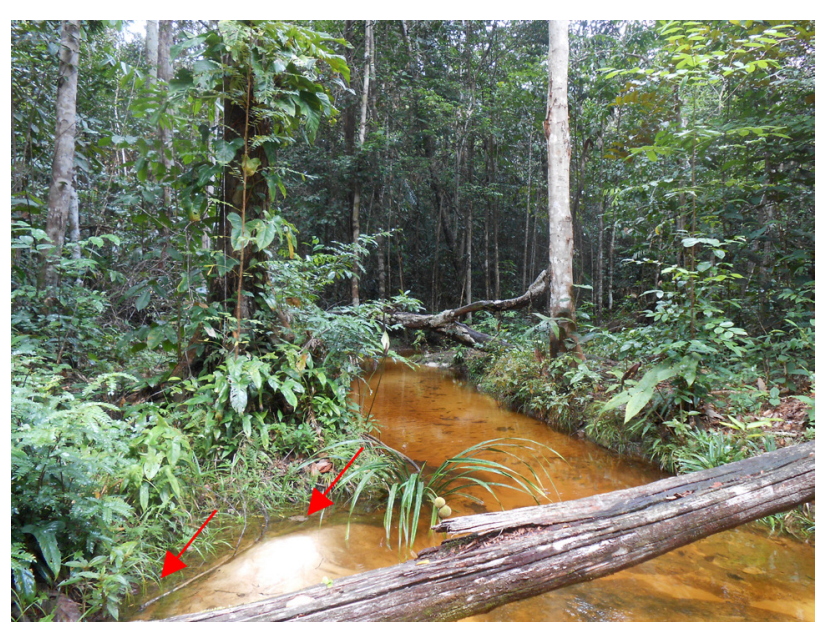

Figure 3. Second-order stream, in Presidente Figueiredo, Amazonas state, Brazil, where the larva of Denopelopia amicitia was collected. This figure is in color in the electronic version.

\section{Distribution and notes on biology}

Denopelopia amicitia is known only from two localities in the Brazilian Amazon. The larva was collected in a preserved second-order stream (sensu Strahler 1957), with sandy bottom at the sampling site (Figure 3). Although immatures of $D$. amicita have been collected both in artificial (Dantas et al. 2016) and natural environments (Figure 3), they seem to be highly associated with aquatic vegetation.

\section{ACKNOWLEDGMENTS}

Thanks are due to Jeferson O. da Silva for help during fieldwork. GPSD received a research fellowships from Conselho Nacional de Desenvolvimento Científico e Tecnológico - CNPq (MCTI/PCI/CNPq proc. 313038/20155 and PDJ/CNPq process \# 150072/2018-0). NH received a CNPq research fellowship (proc. \# 307849/ 2014-7; 308970/2019-5). Photographic infrastructure was provided by Coordenação de Pessoal de Nível Superior - CAPES/ Pro-equipamentos-DCEN. The following projects provided partial financial support: Sistemática integrada de insetos aquáticos na América do Sul (CNPq and Instituto Nacional de Pesquisas da Amazônia - INPA), Sistemática de Insetos aquáticos (PROTAX/CNPq proc.\# 440616/2015-8; CNPq/ MCTI/FAP/PROTAX-FAPEAM).

\section{REFERENCES}

Ashe, P.; O'Connor, J.P. 2009. A world catalogue of Chironomidae (Diptera), part 1. Buchonomyiinae, Chilenomyiinae, Podonominae, Aphroteniinae, Tanypodinae, Usamboramyiinae, Diamesinae, Prodiamesinae and Telmatogetoninae. 1st ed. The National Museum of Ireland, Ireland, 455p.
Cheng, M.; Wang, X. 2005. Denopelopia Roback \& Rutter from China with emendation of the generic diagnosis (Diptera: Chironomidae: Tanypodinae). Zootaxa, 1042: 55-63.

Cranston, P. 2010. Chirokey. Denopelopia. (http://chirokey. skullisland.info/genus/Denopelopia/). Accessed on 05 Apr 2020.

Dantas, G.P.S.; Hamada, N.; Mendes, H.F. 2016. Denopelopia amicitia, a new Tanypodinae from Brazil (Diptera, Chironomidae). ZooKeys, 553: 107-117.

Ekrem, T.; Stur, E.; Hebert, P.D.N. 2010. Females do count: Documenting Chironomidae (Diptera) species diversity using DNA barcoding. Organisms Diversity \& Evolution, 10: 397-408.

Mendes, H.F. 2002. Rearing Tanypodinae, Telmatogetoninae and Orthocladiinae in Brazil - an empirical approach. Chironomus Newsletter, 15: 29-32.

Murray, D.A.; Fittkau E.J. 1989. The adult males of Tanypodinae (Diptera: Chironomidae) of the Holarctic Region - Keys and Diagnoses. In: Wiederholm T (Ed.). The adult males of Chironomidae (Diptera) of the Holarctic region - Keys and diagnoses. Entomologica scandinavica, Supplement, 34: 37-124.

Roback, S.S.; Rutter, P.R. 1988. Denopelopia atria, a new genus and species of Pentaneurini (Diptera: Chironomidae: Tanypodinae) from Florida. Spixiana Supplement, 14: 117-27.

Pinder, L.C.V. 1983. The larvae of Chironomidae (Diptera) of the Holarctic region - Introduction. In: Wiederholm, T. (Ed.). Chironomidae of the Holarctic region - Keys and diagnoses. Part 1. Larvae. Entomologica Scandinavica Supplement, 19: 7-10.

Pinder, L.C.V. 1986. The pupae of Chironomidae (Diptera) of the Holarctic region - Introduction. In: Wiederholm, T. (Ed.). Chironomidae of the Holarctic region - Keys and diagnoses. Part 2. Pupae. Entomologica Scandinavica Supplement, 28: 5-7.

Pinder, L.C.V. 1989. The adult of Chironomidae (Diptera) of the Holarctic region - Introduction. In: Wiederholm T (Ed.). Chironomidae of the Holarctic region. Keys and diagnoses. Part 3. Adult males. Entomologia scandinavica Supplement, 34: 5-9.

Rodova, R.A. 1971. Lichinka i samka Telmatopelopia nemorum (Geotghebuer, 1921) (Diptera: Chironomidae). Trudy Instituta Biologii Vnutrennikh vod Akademii Nauk SSSR, 22: 144-151.

Sæther, O.A. 1977. Female genitalia in Chironomidae and other Nematocera: morphology, phylogenies, keys. Bulletin of the Fisheries Research Board of Canada, 197: 1-211.

Sæther, O.A. 1980. Glossary of chironomid morphology terminology (Diptera: Chironomidae). Entomologica Scandinavica, Supplement, 14: 1-51.

Strahler, A.N. 1957. Quantitative analysis of watershed geomorphology. Transactions, American Geophysical Union, 38: 913-920.

RECEIVED: $14 / 05 / 2020$

ACCEPTED: 03/08/2020

ASSOCIATE EDITOR: Pitágoras C. Bispo 